\title{
Correction to: Sodium, Osmolality, and Antidiuretic Hormone
}

\author{
Luz E. Castellanos
}

\section{Correction to: \\ Chapter 28 in: T. Stanley, M. Misra (eds.), Endocrine Conditions in Pediatrics, https://doi.org/10.1007/978-3-030-52215-5_28}

On page 171, first paragraph of the right-hand text column, the second formula listed for calculated serum osmolality: "([2 * Serum Na in mmol/L] + [Serum glucose in $\mathrm{mg} / \mathrm{dL} / 18]+[$ BUN in $\mathrm{mg} / \mathrm{dL} / 18])$ " was inadvertently published with an error.

This has now been corrected as: "([2 * Serum Na in mmol/L] + [Serum glucose in mg/dL/18] + [BUN in mg/dL/2.8])". 